\title{
Pathologic Stage IV Merkel Cell Carcinoma AJCC v8
}

National Cancer Institute

\section{Source}

National Cancer Institute. Pathologic Stage IV Merkel Cell Carcinoma A/CC v8. NCI

Thesaurus. Code C136889.

Stage IV includes: T0-4, Any N, M1. T0: No evidence of primary tumor. T1: Maximum clinical tumor diameter equal to or less than $2 \mathrm{~cm}$. T2: Maximum clinical tumor diameter more than $2 \mathrm{~cm}$ but equal to or less than $5 \mathrm{~cm}$. T3: Maximum clinical tumor diameter more than $5 \mathrm{~cm}$. T4: Primary tumor invades fascia, muscle, cartilage, or bone. M1: Distant metastasis microscopically confirmed. (AJCC 8th ed.) 